\title{
Ensuring long-term sustainability of existing cohorts remains the highest priority to inform cancer prevention and control
}

\author{
Graham A. Colditz
}

Received: 24 July 2009/Accepted: 23 December 2009/Published online: 9 January 2010

(C) The Author(s) 2010. This article is published with open access at Springerlink.com

\begin{abstract}
The case for continued follow-up of existing cohorts arises from the key attributes of cohorts that are already meeting the goals proposed by Potter for the creation of a new cohort. These attributes include the basic nature of ongoing cohorts in that they are, by design, hypothesis-driven and must adapt to emerging technologies over time. Importantly, cohort investigators must identify and address gaps in knowledge that will inform public health strategies and clinical practices. Above all, cohorts must capitalize on their unique features to address public health priorities and inform our prevention strategies. Continued follow-up adds substantial return on investment to guide cancer prevention.
\end{abstract}

Keywords Cancer prevention - Funding ·

Return on investment · Epidemiology · Prospective . Cohort

The case for continued funding of cohorts has been made in part through previous commentaries [1,2], and in contrast, Potter has called for the creation of a new "last cohort" $[3,4]$. Such a last cohort or large-scale human observational study would include genetics, environment, early-detection markers, molecular classification of outcome, and treatment data to inform clinical practice [3], in fact replicating the existing cohort studies that together follow 4 million men

This article is based on a presentation at the "Cohorts and Consortia" meeting held in Banff, Alberta, Canada, in June 2009.

GAC is supported by ACS Clinical Research Professorship.

G. A. Colditz ( $\square)$

Institute For Public Health, Washington University In St Louis, St. Louis, MO 63110, USA

e-mail: colditzg@wustl.edu; colditzg@wudosis.wustl.edu and women (in 39 cohorts), with over 2 million having germline DNA blood samples stored [5]. Potter indicated that a new cohort focused on the collection of fresh tissue from incident cancer cases should take precedence over continuing the funding of existing cohorts and the inefficient and piecemeal addition of tumor samples to these cohorts [4]. Such fresh tissue would help reduce outcome heterogeneity. Furthermore, in 2005, he argued that cases should be followed to evaluate outcomes and to address survivorship issues; an approach we adopted in the Nurses' Health Study in 1992 by adding quality of life assessment and follow-up of breast cancer cases with subsequent funding to evaluate outcomes (R01AG014742, GAC PI). Here, I build the case for continued follow-up focusing on key attributes of cohorts that are already meeting the goals proposed by Potter for a new cohort and provide a greater return on investment than starting a new "last cohort". These include the basic nature of ongoing cohorts in that they are, by design, hypothesis-driven and must adapt to emerging technologies over time. Importantly, cohort investigators must identify and address gaps in knowledge that will inform public health strategies and clinical practices. Above all, cohorts must capitalize on their unique features to address public health priorities and inform our prevention strategies.

\section{Hypothesis-driven cohorts}

While it is given that cohorts such as other NIH-funded research endeavors must be hypothesis-driven, it is instructive to briefly review the origin of several major cohorts that have helped shape public health in the United States and internationally. Take for example the American Cancer Society cohort studies, which have documented the major 
impact of smoking on cancer and mortality and serve as the basis for CDC projects and global estimates of the burden of tobacco [6]. The British Doctors Study likewise confirmed with a prospective design the original findings of Doll [7, 8] relating smoking to excess lung cancer and other conditions.

The Nurses' Health Study, on the other hand, was established to address the potential relation between use of oral contraceptives and breast cancer and to evaluate relations between smoking and cancer, extending findings to women [9]. The Health Professionals Follow-up Study was first funded to address dietary etiologies of coronary heart disease [10] but then moved to NCI-based funding with a focus on cancer [11]. Other cohorts have been established to address cancer in specific race and ethnic groups: Multiethnic Cohort [12], Black Women's Health Study [13] and the Southern Cohort [14] and specific occupations such as the Agricultural Health Study [15].

\section{Adapting technology}

Numerous examples attest to the adaptive design, development and application of new technologies to further understanding of disease etiology and potential for prevention. Examples range from development and validation of dietary assessment methods for large population studies [16] to collection of blood samples from tens of thousands of study participants $[17,18]$, collection of tissue blocks to provide more detailed classification of endpoints [19], and assessment of lifestyle after diagnosis to document relations to cancer survival [20]. Adapting technology also has refined approaches to conduct cohort studies [21] and to the uses that can be made of formalin-fixed tissue to address biologic mechanisms for exposure-disease relations [22].

Blood samples collected to address hypotheses relating hormones to cancer risk [23] also served to provide DNA for the evaluation of molecular markers [24] and finally to contribute across numerous cohorts to studies of pathways of potential importance in etiology of Breast and Prostate Cancer (BPC3) [25] and then to genome-wide association of SNPs and cancer [26].

\section{Identifying gaps in knowledge}

To fully address the role of lifestyle in cancer etiology and prevention, we must understand when in the course of disease exposure is most important. Examples from breast cancer with the follow-up of survivors from the atomic bomb in Japan attest to the value of cohort studies to define the exposure-disease relation in the time course of life and etiology [27]. Findings such as this also point to the need for studies to address lifestyle during childhood and adolescence in relation to breast cancer risk [28]. Cohorts addressing diet, growth, and cancer risk work to fill this gap in knowledge [29, 30]. Follow-up of childhood cancer survivors offers one important example of such cohort findings relating to clinical practice guidelines [31]. On the other hand, cohorts have been able to supplement existing data resources to fill in gaps in exposure over the life course. For example, the validated measures of selfreported body shape and adiposity [32] added to several cohorts attest to the value of these measures in relation to cancer risk [33]. Likewise, we added recall of high school diet to the Nurses' Health Study and then Nurses' Health Study II [34] and a more detailed assessment of physical activity [35] to further refine our ability to address adolescent exposure and breast cancer risk [36, 37]. Validation shows these measures can be included with adequate performance to detect important relations. The California Teachers Study took this approach from its beginning with assessment of key exposures over the life course and relating these exposures to risk of cancers [38-40].

Clearly in the setting of established data collection, storage, and participant follow-up, the addition of data collection strategies to fill in periods of the life course that may be particularly important offers a valuable and costefficient strategy to uncover details of exposure-disease relations.

Understanding temporal details within exposure-disease relations is essential to inform the timing and population characteristics for prevention strategies. Cohort studies have developed and validated measures of intermediate endpoints such as colon polyps and benign breast lesions, adding these endpoints to the existing cancer endpoints that were of primary importance for initiating the cohort studies [41]. With these endpoints, we can evaluate the timing of diet and activity in relation to precursor lesions, progression to invasive disease, and progression from invasive disease to recurrence and mortality.

Another approach to filling gaps in knowledge has been the establishment of additional cohorts to address specific populations. As noted above, these have often been defined by race or ethnicity or occupation. Another example relates to adolescent exposure and the creation of the Growing Up Today Study. Initial attempts to expand our assessment of diet, physical activity, and growth in relation to subsequent cancer risk were turned down as not innovative or lacking validated measures of diet. With non-federal funds, I led the creation and validation of the adolescent diet assessment tool [42-44] prior to being awarded funds from NICHD to study diet, adiposity, and excess weight gain for gain in height among adolescent children of participants in the Nurses' Health Study II [45]. Again with the mother already participating in the study, additional data sources 
were available (and tracking of participant's long term) at little marginal cost.

Based on these examples, I conclude we should not abandon existing cohorts to reallocate funds to the creation of a new final cohort.

\section{Return on investment grows over time}

Let me explain. The return on investment or sunk costs in established cohorts is substantial, and return on this investment grows over time. Numerous cohorts have added collection of biologic samples to an extensive exposure history and have added additional endpoints to maximize the use of extensive exposure data collection and also allow consideration of trade-offs between risks and benefits of components of lifestyle and other exposures. Furthermore, to address the key question for informing prevention, we must clearly document when in the time course of disease an exposure is important for etiology, at what level of exposure risk of cancer changes, and importantly, how much exposure must change to reduce risk, how long that change must be sustained to achieve a reduction in incidence, and whether there is persisting protection after cessation of exposure. (See Table 1.)

As an example, consider calcium intake and risk of colon cancer. As Martinez and colleagues have elegantly summarized, data from the pooling of prospective studies of diet and cancer show that risk of colon cancer is elevated at very low levels of intake. Risk declines with intake increasing up to about $1,000 \mathrm{mg}$ per day but then flattens with little further reduction in risk with greater intakes (see Fig. 2 in Martinez et al. [48]). Confirming this relation, the Women's Health Initiative randomized women who already had intakes at baseline of approximately $1,151 \mathrm{mg}$ per day and observed minimal change in risk over 5 years of supplementation [49]. Similar issues with the level of intake among study participants also apply to the observed lack of benefit for vitamin D in this trial [49] (see Fig. 1).
Though not interpreted as consistent with the underlying epidemiology by all reporters, these findings nevertheless show the importance of key prevention questions in defining prevention strategies and the value in this case of combined cohort data across many studies to define the levels of exposure necessary to reduce risk.

The example of "filling in" exposure over the life course to understand etiology as described above clearly informs our understanding of exposure and disease etiology. Expanding on this, we can consider the role of cohorts in defining exposure impacting on precursor lesions to a greater (or lesser) extent than on invasive disease or even lifestyle after disease onset and subsequent outcomes. Numerous examples demonstrate these points. For example, the availability of repeated measures of exposure allows us to address change in exposure and change in risk or sustained high exposure and achievable risk reduction. For each of these questions, the cohort offers a broad set of data that with further refinement greatly adds to our understanding and ultimately informs strategies for prevention. Killing (or terminating) existing cohorts would be an incredible waste of existing resources as we continue to address the key question that will transform our population level potential of cancer prevention into focused strategies that achieve the goal of preventing more than half of all cancers in Western societies.

\section{Repeated measures inform prevention}

Numerous components of lifestyle have been addressed capitalizing on the availability of repeated measures in cohort studies. Examples include smoking cessation and continued non-smoking and the decline in incidence of cancer [50]; aspirin and colon cancer [51]; weight loss and breast cancer [52]; and methods development [53]— to name just a few.

Consider aspirin and prevention of colon cancer. Clearly, the time course matters. Epidemiologic data highlighted

Table 1 Questions to frame cancer prevention

\begin{tabular}{|c|c|c|}
\hline Prevention questions & Cohort & Methods issues \\
\hline Which exposure? & Refined measures & Validation and error correction strategies \\
\hline Change by how much? & $\begin{array}{l}\text { Observational cohorts ideally across } \\
\text { broad range of exposure }\end{array}$ & $\begin{array}{l}\text { Consortium adds value of broader exposure } \\
\text { (e.g., EPIC and diet pooling project) }\end{array}$ \\
\hline $\begin{array}{l}\text { Among whom? At what age must } \\
\text { exposure be changed? }\end{array}$ & $\begin{array}{l}\text { Level of exposure } \\
\text { Time course of exposure and disease } \\
\text { development }\end{array}$ & $\begin{array}{l}\text { Consortium adds power to evaluate effects of age. } \\
\text { Intermediate endpoints refine temporal relations }\end{array}$ \\
\hline $\begin{array}{l}\text { How long must change be } \\
\text { sustained? }\end{array}$ & $\begin{array}{l}\text { Duration of altered exposure to modify } \\
\text { cancer incidence }\end{array}$ & $\begin{array}{l}\text { Repeated assessment, updating exposure, refined } \\
\text { measures of duration and continuing adherence }\end{array}$ \\
\hline $\begin{array}{l}\text { Does risk reduction persist after } \\
\text { cessation of exposure? }\end{array}$ & $\begin{array}{l}\text { Updated exposure in cohort essential to } \\
\text { address this question }\end{array}$ & $\begin{array}{l}\text { Follow-up of participants after intervention in trail } \\
\text { setting adds insights here too }[46,47]\end{array}$ \\
\hline
\end{tabular}




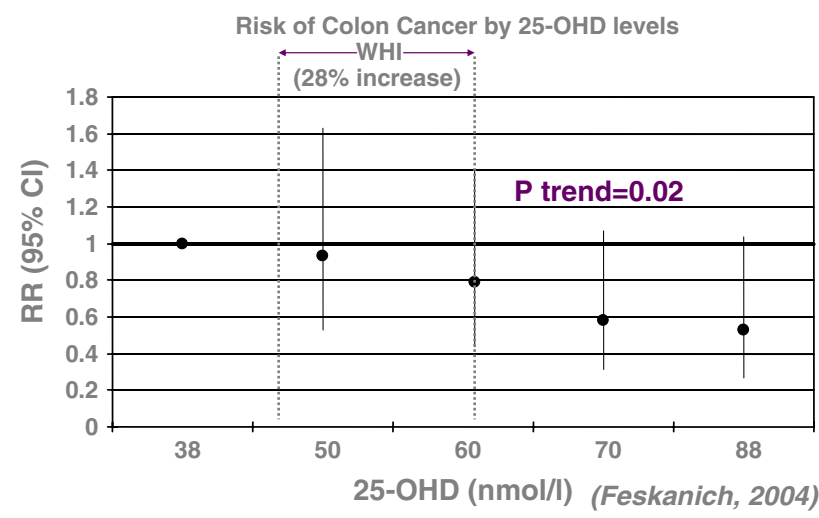

Fig. 1 Vitamin D and colon cancer. Cohort data from Feskanich et al. [64]

the potential for prevention of colon cancer [51, 54], but refining this understanding required repeated measures and intermediate endpoints. For example, in the Health Professionals Follow-up Study, Chan and colleagues showed that both dose and duration of exposure matters-observing a $25 \%$ reduction in risk after 10 years of use and greater reduction with higher dose [54]. Finally, the combined analysis of randomized trials confirmed these epidemiologic associations and demonstrated unequivocally that benefit is not observed until 10 or more years of use [55].

\section{Additional endpoints}

Even greater return on investment is achieved through addition of endpoints for disease onset and for total mortality [15, 56-58]. In each situation, one has the added value of placing exposure-disease relation into a broader public health context by potentially weighing risks and benefits across the multiple endpoints. While such approaches offer challenges in some research settings, such as cancerspecific research institutes and organizations, when other chronic diseases have been added to cohorts, the gain in understanding has been substantial with the marginal cost limited to the documenting of the endpoints as questionnaire-based exposures are already collected and available.

An innovative resource that is added as a complement to the California Teachers Study is the linkage to the California hospital discharge databases (Office of Statewide Health and Planning), which has been validated as a resource for multiple additional endpoints beyond cancer [59]. The investigators thus have put in place permission and systems to use this resource to capitalize on the cohort to address a broader range of health issues, placing exposure and outcomes for cancer in the context of other major health events and also enriching the self-report data with the history of gynecologic and other surgeries that may modify cancer risk. This added resource has supported discovery with publication of the first paper on the epidemiology and correlates of adenomyosis (a condition that, although similar to endometriosis, affects the inner lining of the uterus) [60]. They have also published on predictors of surgery for endometriosis and fibroids in the cohort [61]. As the added value of additional endpoints becomes more widely recognized, other cohorts are linking to records for identification of non-cancer outcomes [62].

In summary, return on investment can be considered through the gains as outlined above:

Understanding the time course of disease

Evaluating change in behavior and change in disease risk Adding endpoints to evaluate the exposures in relation to multiple diseases at low marginal cost and balancing risks and benefits of exposures/behaviors.

As I have emphasized in previous writing on cohorts [1], maintaining high follow-up rates is key to internal validity. This reflects, in part, the adaptive nature of cohort studies. Use of web-based approaches to follow participants, e-mail in addition to postal addresses, and the like, attest to the adaptability of this design. In addition, ongoing quality control measures are needed within those cohorts that rely on tumor registry linkages for confirmation of incident cancers as performance of linkages can vary over time.

\section{Evaluating cohorts}

Within the NCI Division of Cancer Control and Population Sciences (DCCPS), increasing emphasis on evaluation of major initiatives has placed led to new strategies to quantify collaborative research [63]? Despite the overall contribution of cohorts to cancer prevention, how does one evaluate specific cohorts and potentially chose among them for continued funding and follow-up? With Debbie Winn, we proposed a set of metrics to evaluate large initiatives such as cohorts within the NCI Division of Cancer Prevention and Population Sciences [64]. These are summarized below:

\section{- Discovery}

- To explain the etiology of diseases and health conditions (e.g., journal articles, impact factors)

- Development

- To provide a basis for developing control measures and prevention procedures for groups and populations at risk (e.g., determination of causes, public health guidelines, risk models) 


\section{- Delivery}

- Implementation, use of findings, evidence-based public health policy and clinical guidelines (e.g., public awareness, policy applications)

While we applied these metrics to the Nurses' Health Study as an example in our original writing, application to other cohorts confirm the utility of these measures. For example, under discovery metrics, including journal publications and the impact ranking of the journals, we showed that publications during the first 10 years of a cohort are typically minor. In the Nurses' Health Study, these were largely cross-sectional studies and amounted to a total of 25 papers in the first 10 years of follow-up [64]. Review of the Childhood Cancer Survivor Study cohort [65] that draws on a population of 14,000 5-year childhood cancer survivors has endpoints arising far more rapidly than in an etiology or primary prevention setting, yet still shows the slow take-off in publications that reflect the time and investment in establishing a cohort and the accompanying methods for follow-up (see Fig. 2). During these first 10 years, papers tend to be in discipline-specific journals and high impact publications tend to develop as the cohort matures. Of note, the CCSS has 44 percent of its publications through June 2009, in journals with impact factor of 10 or higher.

Development metrics ask that findings from cohorts provide a basis for developing cancer control measures and prevention procedures for groups and populations at risk (e.g., determination of causes, public health guidelines, and disease risk classification models). Again, NHS-related contributions are summarized previously [64]. Here, the CCSS provides several examples that translate ongoing findings from the follow-up of childhood cancers to prevention/intervention strategies [65].

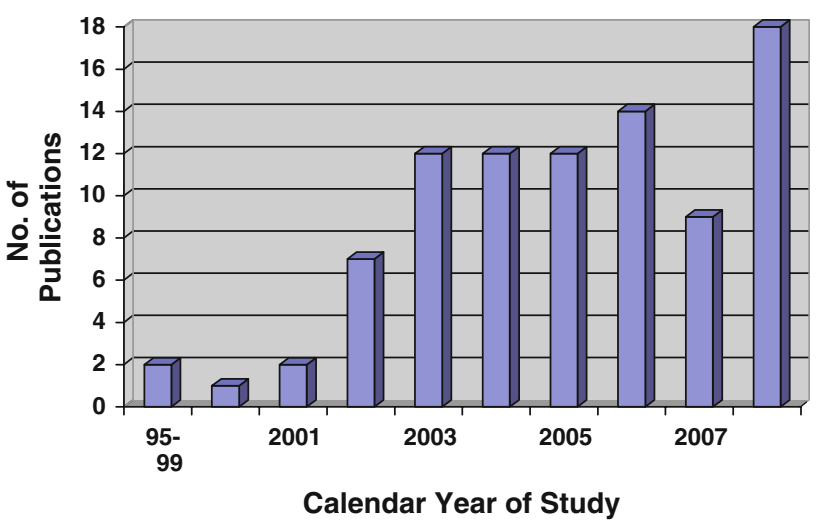

Fig. 2 Annual publications from Childhood Cancer Survivor Study, 1995-2008
Delivery metrics include implementation, or use of findings, to guide evidence-based public health policy and clinical guidelines or policy applications. The CCSS shows the direct translation of their findings to clinical management guidelines, where the cohort has facilitated identification of childhood cancer survivor populations at high risk for specific organ toxicity and secondary carcinogenesis, which has directly informed clinical screening practices [66, 67].

Other applications of these metrics to cohorts support their use for the evaluation of these studies. Publications from GUTS, for example, follow the pattern of the NHS and CCSS but with a stronger push for early publications to sustain funding, and accordingly a number of papers in leading discipline journals were published in the first 5 years using prospective data as were methods papers drawing on the cohort.

\section{Closing cohorts}

The lifespan of cohorts is not clear a priori-the British Doctors Study has followed participants from the baseline "questionary" through 50 years [68]. Other cohorts are continuing to mature, and some have ceased follow-up [6]. While individual cohorts may be evaluated against the metrics of discovery, development, and delivery, we might also consider the issues addressed under return on investment. The changing patterns of exposure, new populations defined by birth cohort, and immigration, all suggest that from a public health perspective, NIH must balance a portfolio of cohorts to adequately address lifestyle, occupation, and other factors that are best evaluated through long-term prospective cohort studies. Perhaps those cohorts that are not best adapting to changing technologies and understanding of disease processes and are not updating exposure information after diagnosis (or similar factors outlined under return on investment) should receive lower priority for continued funding. Thus, in addition to the evaluation of specific hypotheses for cohort competitive renewal, we might also evaluate and score the contribution to discovery, development and delivery and return on investment to date, and the potential for return in the next and 10 years should renewal funding be implemented.

\section{Conclusion}

In sum, cohorts are complex and most informative when exposures are updated or multiple endpoints are addressed. Most importantly for cancer etiology and prevention, they can place exposure in the time course of disease development to address key questions of timing and magnitude of change necessary to result in prevention of cancer. 
Furthermore, when multiple endpoints are addressed, they can place etiology and prevention in broad public health context giving insights to the trades-offs of risks and benefits of lifestyle and lifestyle changes. Established modern cohorts clearly support numerous scientific investigations beyond the primary etiologic hypotheses defined to justify cohort follow-up. Based on these considerations, it is clear that the return on investment of established cohorts can increase over time, and careful consideration should be given to the allocation of resources to maximize the pay-off for informing prevention strategies.

Acknowledgments Drs L Robison and L Bernstein provided up-todate information on the cohorts they lead including details of cohort publications.

Open Access This article is distributed under the terms of the Creative Commons Attribution Noncommercial License which permits any noncommercial use, distribution, and reproduction in any medium, provided the original author(s) and source are credited.

\section{References}

1. Colditz GA (2007) Cohort studies of etiology and survival after cancer: the unique needs for uninterrupted funding. Cancer Causes Control 18(3):235-241

2. Willett WC, Blot WJ, Colditz GA, Folsom AR, Henderson BE, Stampfer MJ (2007) Merging and emerging cohorts: not worth the wait. Nature 445(7125):257-258

3. Potter JD (2005) Epidemiology informing clinical practice: from bills of mortality to population laboratories. Nat Clin Pract Oncol 2(12):625-634

4. Potter JD (2004) Toward the last cohort. Cancer Epidemiol Biomarkers Prev 13(6):895-897

5. National Cancer Institute. Cohort Consortium (2009) Available from: http://epi.grants.cancer.gov/Consortia/cohort.html. Cited 2009

6. Thun MJ, Calle EE, Rodriguez C, Wingo PA (2000) Epidemiological research at the American cancer society. Cancer Epidemiol Biomarkers Prev 9(9):861-868

7. Doll R, Hill A (1950) Smoking and carcinoma of the lung: preliminary report. BMJ 30:739-748

8. Doll R, Hill A (1954) The mortality of doctors in relation to their smoking habits. A preliminary report. BMJ 26:1451-1455

9. Colditz GA, Manson JE, Hankinson SE (1997) The nurses' health study: 20-year contribution to the understanding of health among women. J Womens Health 6(1):49-62

10. Rimm EB, Giovannucci EL, Willett WC, Colditz GA, Ascherio A, Rosner B, Stampfer MJ (1991) Prospective study of alcohol consumption and risk of coronary disease in men. Lancet 338:464-468

11. Giovannucci E, Rimm EB, Stampfer MJ, Colditz GA, Ascherio A, Willett WC (1994) Intake of fat, meat, and fiber in relation to risk of colon cancer in men. Cancer Res 54:2390-2397

12. Haiman CA, Stram DO, Wilkens LR, Pike MC, Kolonel LN, Henderson BE, Le Marchand L (2006) Ethnic and racial differences in the smoking-related risk of lung cancer. N Engl J Med 354(4):333-342

13. Rosenberg L, Adams-Campbell L, Palmer JR (1995) The black women's health study: a follow-up study for causes and preventions of illness. J Am Med Womens Assoc 50(2):56-58
14. Cohen SS, Signorello LB, Gammon MD, Blot WJ (2007) Obesity and recent mammography use among black and white women in the Southern Community Cohort Study (United States). Cancer Causes Control 18(7):765-773

15. Blair A, Sandler D, Thomas K, Hoppin JA, Kamel F, Coble J, Lee WJ, Rusiecki J, Knott C, Dosemeci M, Lynch CF, Lubin J, Alavanja M (2005) Disease and injury among participants in the agricultural health study. J Agric Saf Health 11(2):141-150

16. Willett W (1998) Chapter 1: overview of nutritional epidemiology. In: Willett W (ed) Nutritional epidemiology. Oxford University Press, New York

17. Hankinson SE, London SJ, Chute CG, Barbieri RL, Jones L, Kaplan LA, Sacks FM, Stampfer MJ (1989) Effect of transport conditions on the stability of biochemical markers in blood. Clin Chem 35:2313-2316

18. Hankinson SE, Manson JE, Spiegelman D, Willett WC, Longcope C, Speizer FE (1995) Reproducibility of plasma hormone levels in postmenopausal women over a 2-3-year period. Cancer Epidemiol Biomakers Prevention 4:649-654

19. Tamimi RM, Baer HJ, Marotti J, Galan M, Galaburda L, Fu Y, Deitz AC, Connolly JL, Schnitt SJ, Colditz GA, Collins LC (2008) Comparison of molecular phenotypes of ductal carcinoma in situ and invasive breast cancer. Breast Cancer Res 10(4):R67

20. Holmes MD, Chen WY, Feskanich D, Kroenke CH, Colditz GA (2005) Physical activity and survival after breast cancer diagnosis. JAMA 293(20):2479-2486

21. Willett W, Colditz G (1999) Approaches to conducting large cohort studies. Epidemiol Rev 20:91-99

22. Ogino S, Nosho K, Kirkner GJ, Kawasaki T, Chan AT, Schernhammer ES, Giovannucci EL, Fuchs CS (2008) A cohort study of tumoral LINE-1 hypomethylation and prognosis in colon cancer. J Natl Cancer Inst 100(23):1734-1738

23. Endogenous Hormones and Breast Cancer Collaborative Group (2002) Endogenous sex hormones and breast cancer in postmenopausal women: reanalysis of nine prospective studies. J Natl Cancer Inst 94((8):606-616

24. Haiman CA, Hankinson SE, Spiegelman D, Colditz GA, Willett WC, Speizer FE, Kelsey KT, Hunter DJ (1999) The relationship between a polymorphism in CYP17 with plasma hormone levels and breast cancer. Cancer Res 59(5):1015-1020

25. Hunter DJ, Riboli E, Haiman CA, Albanes D, Altshuler D, Chanock SJ, Haynes RB, Henderson BE, Kaaks R, Stram DO, Thomas G, Thun MJ, Blanche H, Buring JE, Burtt NP, Calle EE, Cann H, Canzian F, Chen YC, Colditz GA, Cox DG, Dunning AM, Feigelson HS, Freedman ML, Gaziano JM, Giovannucci E, Hankinson SE, Hirschhorn JN, Hoover RN, Key T, Kolonel LN, Kraft P, Le Marchand L, Liu S, Ma J, Melnick S, Pharaoh P, Pike MC, Rodriguez C, Setiawan VW, Stampfer MJ, Trapido E, Travis R, Virtamo J, Wacholder S, Willett WC (2005) A candidate gene approach to searching for low-penetrance breast and prostate cancer genes. Nat Rev Cancer 5(12):977-985

26. Hunter DJ, Kraft P, Jacobs KB, Cox DG, Yeager M, Hankinson SE, Wacholder S, Wang Z, Welch R, Hutchinson A, Wang J, Yu K, Chatterjee N, Orr N, Willett WC, Colditz GA, Ziegler RG, Berg CD, Buys SS, McCarty CA, Feigelson HS, Calle EE, Thun MJ, Hayes RB, Tucker M, Gerhard DS, Fraumeni JF Jr, Hoover RN, Thomas G, Chanock SJ (2007) A genome-wide association study identifies alleles in FGFR2 associated with risk of sporadic postmenopausal breast cancer. Nat Genet 39(7):870-874

27. Land CE, Tokunaga M, Koyama K, Soda M, Preston DL, Nishimori I, Tokuoka S (2003) Incidence of female breast cancer among atomic bomb survivors, Hiroshima and Nagasaki, 19501990. Radiat Res 160(6):707-717

28. Colditz GA, Frazier AL (1995) Models of breast cancer show that risk is set by events of early life: prevention efforts must shift focus. Cancer Epidemiol Biomarkers Prev 4(5):567-571 
29. Berkey CS, Frazier AL, Gardner JD, Colditz GA (1999) Adolescence and breast carcinoma risk. Cancer 85(11):2400 2409

30. Berkey CS, Colditz GA, Rockett HR, Frazier AL, Willett WC (2009) Dairy consumption and female height growth: prospective cohort study. Cancer Epidemiol Biomarkers Prev 18(6):18811887

31. Oeffinger KC, Ford JS, Moskowitz CS, Diller LR, Hudson MM, Chou JF, Smith SM, Mertens AC, Henderson TO, Friedman DL, Leisenring WM, Robison LL (2009) Breast cancer surveillance practices among women previously treated with chest radiation for a childhood cancer. JAMA 301(4):404-414

32. Must A, Willett WC, Dietz WH (1993) Remote recall of childhood height, weight, and body build by elderly subjects. Am J Epidemiol 138:56-64

33. Baer HJ, Colditz GA, Rosner B, Michels KB, Rich-Edwards JW, Hunter DJ, Willett WC (2005) Body fatness during childhood and adolescence and incidence of breast cancer in premenopausal women: a prospective cohort study. Breast Cancer Res 7(3): R314-R325

34. Maruti SS, Feskanich D, Rockett HR, Colditz GA, Sampson LA, Willett WC (2006) Validation of adolescent diet recalled by adults. Epidemiology 17(2):226-229

35. Maruti SS, Willett WC, Feskanich D, Levine B, Rosner B, Colditz GA (2009) Physical activity and premenopausal breast cancer: an examination of recall and selection bias. Cancer Causes Control 20(5):549-558

36. Baer HJ, Schnitt SJ, Connolly JL, Byrne C, Cho E, Willett WC, Colditz GA (2003) Adolescent diet and incidence of proliferative benign breast disease. Cancer Epidemiol Biomarkers Prev 12(11 Pt 1):1159-1167

37. Maruti SS, Willett WC, Feskanich D, Rosner B, Colditz GA (2008) A prospective study of age-specific physical activity and premenopausal breast cancer. J Natl Cancer Inst

38. Dallal CM, Sullivan-Halley J, Ross RK, Wang Y, Deapen D, Horn-Ross PL, Reynolds P, Stram DO, Clarke CA, Anton-Culver H, Ziogas A, Peel D, West DW, Wright W, Bernstein L (2007) Long-term recreational physical activity and risk of invasive and in situ breast cancer: the California teachers study. Arch Intern Med 167(4):408-415

39. Mai PL, Sullivan-Halley J, Ursin G, Stram DO, Deapen D, Villaluna D, Horn-Ross PL, Clarke CA, Reynolds P, Ross RK, West DW, Anton-Culver H, Ziogas A, Bernstein L (2007) Physical activity and colon cancer risk among women in the California teachers study. Cancer Epidemiol Biomarkers Prev 16(3):517-525

40. Reynolds P, Hurley S, Goldberg DE, Anton-Culver H, Bernstein L, Deapen D, Horn-Ross PL, Peel D, Pinder R, Ross RK, West D, Wright WE, Ziogas A (2004) Active smoking, household passive smoking, and breast cancer: evidence from the California teachers study. J Natl Cancer Inst 96(1):29-37

41. Colditz GA, Hankinson SE (2005) The nurses' health study: lifestyle and health among women. Nat Rev Cancer 5(5):388-396

42. Rockett HR, Wolf AM, Colditz GA (1995) Development and reproducibility of a food frequency questionnaire to assess diets of older children and adolescents. J Am Diet Assoc 95(3): 336-340

43. Rockett H, Breitenbach M, Frazier A, Witschi J, Wolf A, Field A, Colditz G (1997) Validation of a youth/adolescent food frequency questionnaire. Prev Med 26:808-816

44. Rockett HR, Colditz GA (1997) Assessing diets of children and adolescents. Am J Clin Nutr 65(4 Suppl):1116S-1122S

45. Berkey C, Rockett H, Field A, Gillman M, Frazier A, Camargo C, Colditz G (2000) Activity, dietary intake and weight change in a longitudinal study of adolescent boys and girls. Pediatrics 105:E56
46. Grau MV, Baron JA, Sandler RS, Wallace K, Haile RW, Church TR, Beck GJ, Summers RW, Barry EL, Cole BF, Snover DC, Rothstein R, Mandel JS (2007) Prolonged effect of calcium supplementation on risk of colorectal adenomas in a randomized trial. J Natl Cancer Inst 99(2):129-136

47. Qiao YL, Dawsey SM, Kamangar F, Fan JH, Abnet CC, Sun XD, Johnson LL, Gail MH, Dong ZW, Yu B, Mark SD, Taylor PR (2009) Total and cancer mortality after supplementation with vitamins and minerals: follow-up of the Linxian general population nutrition intervention trial. J Natl Cancer Inst 101(7):507518

48. Martinez ME, Marshall JR, Giovannucci E (2008) Diet and cancer prevention: the roles of observation and experimentation. Nat Rev Cancer

49. Wactawski-Wende J, Kotchen JM, Anderson GL, Assaf AR, Brunner RL, O'Sullivan MJ, Margolis KL, Ockene JK, Phillips L, Pottern L, Prentice RL, Robbins J, Rohan TE, Sarto GE, Sharma S, Stefanick ML, Van Horn L, Wallace RB, Whitlock E, Bassford T, Beresford SA, Black HR, Bonds DE, Brzyski RG, Caan B, Chlebowski RT, Cochrane B, Garland C, Gass M, Hays J, Heiss G, Hendrix SL, Howard BV, Hsia J, Hubbell FA, Jackson RD, Johnson KC, Judd H, Kooperberg CL, Kuller LH, LaCroix AZ, Lane DS, Langer RD, Lasser NL, Lewis CE, Limacher MC, Manson JE (2006) Calcium plus vitamin D supplementation and the risk of colorectal cancer. N Engl J Med 354(7):684-696

50. Kenfield SA, Stampfer MJ, Rosner BA, Colditz GA (2008) Smoking and smoking cessation in relation to mortality in women. JAMA 299(17):2037-2047

51. Chan AT, Giovannucci EL, Meyerhardt JA, Schernhammer ES, Curhan GC, Fuchs CS (2005) Long-term use of aspirin and nonsteroidal anti-inflammatory drugs and risk of colorectal cancer. JAMA 294(8):914-923

52. Eliassen AH, Colditz G, Rosner B, Willett W, Hankinson SE (2006) Adult weight change and risk of postmenopausal breast cancer. JAMA 296:193-201

53. Rosner B, Gore R (2001) Measurement error correction in nutritional epidemiology based on individual foods, with application to the relation of diet to breast cancer. Am J Epidemiol 154(9):827-835

54. Chan AT, Giovannucci EL, Meyerhardt JA, Schernhammer ES, Wu K, Fuchs CS (2008) Aspirin dose and duration of use and risk of colorectal cancer in men. Gastroenterology 134(1):21-28

55. Gralow J, Ozols RF, Bajorin DF, Cheson BD, Sandler HM, Winer EP, Bonner J, Demetri GD, Curran W Jr, Ganz PA, Kramer BS, Kris MG, Markman M, Mayer RJ, Raghavan D, Ramsey S, Reaman GH, Sawaya R, Schuchter LM, Sweetenham JW, Vahdat LT, Davidson NE, Schilsky RL, Lichter AS (2008) Clinical cancer advances 2007: major research advances in cancer treatment, prevention, and screening-a report from the American society of clinical oncology. J Clin Oncol 26(2):313-325

56. Colditz G (1994) For the NHS research group. Oral contraceptive use and mortality during twelve years of follow-up. Ann Intern Med 120:821-826

57. Fuchs CS, Stampfer MJ, Colditz GA, Giovannucci EL, Manson JE, Kawachi I, Hunter DJ, Hankinson SE, Hennekens CH, Rosner B, Speizer FE, Willett WC (1995) Alcohol consumption and mortality among women. N Engl J Med 332:1245-1250

58. Thun MJ, Peto R, Lopez AD, Monaco JH, Henley SJ, Heath CW Jr, Doll R (1997) Alcohol consumption and mortality among middle-aged and elderly U.S. adults. N Engl J Med 337:17051714

59. Marshall SF, Deapen D, Allen M, Anton-Culver H, Bernstein L, Horn-Ross PL, Peel D, Pinder R, Reynolds P, Ross RK, West D, Ziogas A (2003) Validating California teachers study self-reports of recent hospitalization: comparison with California hospital discharge data. Am J Epidemiol 158(10):1012-1020 
60. Templeman C, Marshall SF, Ursin G, Horn-Ross PL, Clarke CA, Allen M, Deapen D, Ziogas A, Reynolds P, Cress R, AntonCulver H, West D, Ross RK, Bernstein L (2008) Adenomyosis and endometriosis in the California teachers study. Fertil Steril 90(2):415-424

61. Templeman C, Marshall SF, Clarke CA, Delellis Henderson K, Largent J, Neuhausen S, Reynolds P, Ursin G, Bernstein L (2008) Risk factors for surgically removed fibroids in a large cohort of teachers. Fertil Steril

62. Maskarinec G, Erber E, Grandinetti A, Verheus M, Oum R, Hopping BN, Schmidt MM, Uchida A, Juarez DT, Hodges K, Kolonel LN (2009) Diabetes incidence based on linkages with health plans: the multiethnic cohort. Diabetes 58(8):1732-1738

63. Hall KL, Stokols D, Moser RP, Taylor BK, Thornquist MD, Nebeling LC, Ehret CC, Barnett MJ, McTiernan A, Berger NA, Goran MI, Jeffery RW (2008) The collaboration readiness of transdisciplinary research teams and centers findings from the National Cancer Institute's TREC year-one evaluation study. Am J Prev Med 35(2 Suppl):S161-S172

64. Colditz GA, Winn DM (2008) Criteria for the evaluation of large cohort studies: an application to the nurses' health study. J Natl Cancer Inst 100(13):918-925

65. Robison LL, Armstrong GT, Boice JD, Chow EJ, Davies SM, Donaldson SS, Green DM, Hammond S, Meadows AT, Mertens
AC, Mulvihill JJ, Nathan PC, Neglia JP, Packer RJ, Rajaraman P, Sklar CA, Stovall M, Strong LC, Yasui Y, Zeltzer LK (2009) The childhood cancer survivor study: a National Cancer Institutesupported resource for outcome and intervention research. J Clin Oncol 27(14):2308-2318

66. Hudson MM, Mulrooney DA, Bowers DC, Sklar CA, Green DM, Donaldson SS, Oeffinger KC, Neglia JP, Meadows AT, Robison LL (2009) High-risk populations identified in childhood cancer survivor study investigations: implications for risk-based surveillance. J Clin Oncol 27(14):2405-2414

67. Landier W, Bhatia S, Eshelman DA, Forte KJ, Sweeney T, Hester AL, Darling J, Armstrong FD, Blatt J, Constine LS, Freeman CR, Friedman DL, Green DM, Marina N, Meadows AT, Neglia JP, Oeffinger KC, Robison LL, Ruccione KS, Sklar CA, Hudson MM (2004) Development of risk-based guidelines for pediatric cancer survivors: the children's oncology group long-term follow-up guidelines from the children's oncology group late effects committee and nursing discipline. J Clin Oncol 22(24):4979-4990

68. Doll R, Peto R, Boreham J, Sutherland I (2005) Mortality from cancer in relation to smoking: 50 years observations on British doctors. Br J Cancer 92(3):426-429 